\title{
Kasvatusta vai sosialisaatiota?
}

Risto Ikonen

\author{
Näyttää siltä, että kasvatuksen ja sosialisaation välinen \\ rajanveto ei vieläkään ole täysin loppuun saatettu. \\ Väitetään, että kasvatus on sosialisaatiota. Toisaalta taas \\ on todettu, että kasvatustoiminnan erityislaatu tekee \\ siitä sosialisaatioon nähden täysin erillisen ilmiön. \\ Näkemysero on kiistaton.
}

Kirjoittaja puolustaa artikkelissa näkemystä siitä, että

kasvatus on sosialisaation yksi muoto ja sosialisaation

alakäsite.

Arkielämässä käsitysten vastakkaisuus kasvatuksen ja sosialisaation keskinäisestä samuudesta tai riippumattomuudesta voidaan sivuuttaa varsin kepeästi ('makunsa kullakin'), mutta näin ei voida toimia tieteellisessä puheyhteisössä. Käsitysten ristiriita merkitsee ymmärrysten ristiriitaa, ja tieteellisessä tiedonmuodostuksessa on välttämätöntä selvittää, mistä syystä eri ihmiset ymmärtävät jonkun asian eri tavoin. Siksi on perehdyttävä käsitysten taustalla oleviin seikkoihin. Tämä on tärkeää jo pelkästään siitä syystä, että erilaisiin näkökantoihin perehtyminen tarjoaa samalla erilaisia näkökulmia tarkastelun kohteena olevaan ilmiöön. Viime kädessä taustaoletusten selvittely tähtää kuitenkin ristiriidan ratkaisuun. Jompi kumpi käsityksistä saattaa olla se oikea, tai sitten molemmat ovat osin oikeassa ja osin väärässä. Jälkimmäisessä tapauksessa taustojen selvittelijä joutuu itse esittämään oman käsityksensä ilmiön todellisesta luonteesta.

Koetan tässä artikkelissa etsiä ratkaisua kasvatuksen ja sosialisaation välistä suhdetta koskevaan kiistaan. Perinteisen määritelmän mukaisesti sosialisaatiolla tarkoitetaan yksilön sopeutumista ympäröivään yhteisöön ja erittäinkin siinä vallitseviin arvoihin, normeihin ja rooleihin. Sosialisaation edetessä yksilö harjaantuu toimimaan yhteiskunnassa. (ks. Bertram 1989). Käsitystä on kritisoitu siitä, ettei se ota huomioon yksilön omaa osuutta sosialisaatioprosessissa. Lisäksi siinä korostuu yhteisöelämän muuttumattomuus, status quo. Vaihtoehtoinen määritelmä kuuluukin: Sosialisaatio on persoonallisuuden kehittymistä, joka tapahtuu vuorovaikutuksessa tietyn materiaalisen ja sosiaalisen ympäristön kanssa. (Geulen 1989; Gecas 1992). Tässä prosessissa kehittyvät sosiaalisen toiminnan peruskvalifikaatiot, so. tietyssä kulttuurissa toimimiseen tarvittava arvojen, tietojen ja taitojen kokonaisuus (ks. myös Bertram 1989; Siljander 1997, 9; Sturman 1997).

Tos sosialisaatio katsotaan prosessiksi, jossa yksilö tavoittaa yhteisössä toimimiseen tarvittavat perustiedot ja -taidot, voisi hyvin ajatella, että kasvatus olisi aina väistämättä myös sosialisaatiota (ks. Antikainen 1993, 1998). Kaikki eivät kuitenkaan hyväksy tätä käsitystä. Niinpä on väitetty, että pedagogisen teorianmuodostuksen 


\section{A R T I K K E L I T}

kannalta ei ole ongelmatonta eikä liioin tyydyttävää samaistaa kasvatusta sosialisaatioon tai edes pitää kasvatusta sosialisaation alakäsitteenä (Siljander 1997, 10; ks. myös Kivelä 1997, 56 ja Peltonen 1997, 23). Yksilön kehityshistorian näkökulmasta tarkasteltuna tämä väite - tai paremminkin sen loppuosa - kummastuttaa. Miten ihmeessä kasvatuksen sijoittaminen sosialisaation alakäsitteeksi voisi olla ongelmallista? Jos sosialisaation katsotaan olevan inhimilliseen elinympäristöön kuuluva vastinpari sopeutumiselle fyysiseen elinympäristöön [1], kuinka kasvatuksen voitaisiin ajatella olevan mitään muuta kuin juuri sosialisaatiota? Tämä ei kuitenkaan merkitse sitä, että sanaa 'kasvatus' olisi pidettävä synonyymisena (tai ekvivalenttisena) sanalle 'sosialisaatio'. Ajatus on yhtä mielekäs kuin, jos sanan 'ihminen' väitettäisiin olevan ekvivalenttinen sanan 'nisäkäs' kanssa. Tästähän seuraisi, että koska rotta on 'nisäkäs', se samalla olisi 'ihminen'. Tietenkään kasvatus ei ole sama asia kuin sosialisaatio. Toisaalta on vaikea kuvitella, miksi kasvatus ei olisi yksi sosialisaation muoto. Millä perustein yhteisön toimintakykyiseksi jäseneksi kehittymisen prosessia voitaisiin pitää kokonaan eri asiana kuin kasvatusta?

\section{Onko pedagoginen toiminta eri asia kuin sosialisaatio?}

$\mathrm{V}_{\mathrm{p}}$

astausta kasvatuksen ja sosialisaation väliseen problematiikkaan voidaan etsiä tarkastelemalla lähemmin näiden kahden ilmiön erillisyyttä korostavia ajatussuuntauksia. Yksi tällainen on pedagogisen toiminnan teoria, jossa kasvatuksen katsotaan erovan laadullisesti sosialisaatiosta [2]. Ero on kiteytetty neljään pedagogista toimintaa luonnehtivaan erityispiirteeseen (ks. Kivelä 1997, 39):

1) sivistyksellisyys (Bildsamkeit)

2) vaatimus itsenäiseen toimintaan (Aufforderung zur Selbsttätigkeit)

3 ) kulttuurin presentaatio

4) kulttuurin representaatio

Näihin piirteisiin pitäisi kasvatuksen erityislaadun ja erillisyyden perustua, ja ensikatsannolta erottelu näyttäisikin puoltavan paikkaansa. Mut-

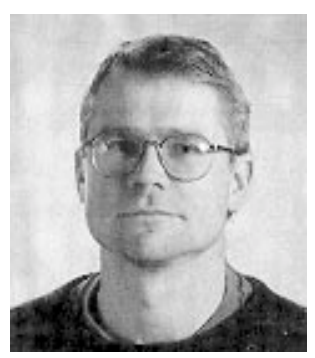

Risto Ikonen

ta onko todella näin? Asian selvittämiseksi on käytävä luettelo kohta kohdalta läpi ja tutkittava, riittävätkö luetellut erityispiirteet tekemään kasvatuksesta oman erillisen ilmiönsä.

E nsimmäisenä piirteenä mainitaan sivistykselisyys. Mitähän se mahtaisi tarkoittaa? Kivelän mukaan sivistyksellisyys-periaatteella on kaksi merkitystä. Ensinnäkin se viittaa siihen, että ihminen on määrätty vapauteen. Hän kykenee kehittymään ja kasvamaan sosiokulttuurisen ja fyysisen maailman ristipaineessa. Sivistyksellisyys sisältää siten vapauden periaatteen. Konkreetimman merkitysvariantin mukaan sivistyksellisyys viittaa sivistyksen interaktio- ja suhdeluonteeseen. Sivistyksellisyys muotoutuu, määrittyy ja mahdollistuu pedagogisessa interaktiossa. Tällöin kasvava ymmärretään sivistyksellisenä olentona. (Kivelä 1997, 39-40). Näin ollen sivistyksellisyyttä voidaan pitää kasvavan avoimena ja määrittelemättömänä mahdollisuutena tai taipumuksena —-"käyttää kieltä, toimia maailmassa ja sen muodostamassa historiallisessa horisontissa" (mt. 40). Mutta eroaako tämä sitten millään tavoin sosialisaatiosta? Nähdäkseni ei. Sosialisaation nimikkeen alla voidaan aivan hyvin puhua myös vapaudesta, ihmisten välisestä vuorovaikutuksesta tai kulttuuristen perustietojen ja -taitojen omaksumisesta.

Miksi Kivelä sitten puhuu juuri sivistyksellisyydestä? Katsotaanpas argumentaatiota hieman tarkemmin. Kivelä toteaa, että pedagogisessa interaktiossa —-kasvattaja tekee aina enemmän tai vähemmän tietoisen oletuksen kasvavan sivistyksellisyydestä” (Kivelä 1997, 40). Tästä huomautuksesta näyttäisi löytyvän vastaus esi- 
tettyyn kysymykseen. Kysehän on sivistysasteen (tai laadun) arvioinnista, ja tämä taas antaa syyn olettaa, että olisi olemassa jokin ideaalinen sivistyksellisyys, jota kohden ihmiset ovat enemmän tai vähemmän menestyksekkäästi pyrkimässä. Ylipäätään näyttäisi siltä, että kasvatusta sivistymisprosessina kuvaavat ajatussuuntaukset rakentuvat ideaalisen ihmiskuvan varaan (ks. MeyerDrawe 1999). Mutta jos tämä askel otetaan, silloin sivistysprosessin idea ei voi tarjota yleispätevää perustaa kasvatuksen käsitteelliselle haltuunotolle. Kysehän olisi vain yhdestä mahdollisesta kasvatuskäsityksestä, nimittäin sellaisesta, joka rakentuu tietynlaiselle ihmisihanteelle.

$\mathrm{L}$ iioin yksilön autonomisuuden idea - jota pidetään sivistysprosessin yhtenä tunnusmerkeistä (Kivelä 1997, 40-41; Peltonen 1997, 27 28) - ei voine tarjota pitävää perustaa kasvatuksen käsitteelle. Ensinnäkin autonomisuuden käsite on kovin problemaattinen. Sen ytimenähän on ajatus ihmisestä, jonka toimia eivät ohjaa ulkopuolelta annetut vaikutteet. Mutta voiko tätä tilaa lainkaan saavuttaa? Varsinkin kasvatuksen osalta kysymys on erinomaisen vaikea, pyritäänhän siinä tietoisesti vaikuttamaan kasvatettavaan. Onnistuessaan kasvatus siis merkitsee väistämättä kasvatettavan autonomian - itseohjautuvuuden ja itsemääräytyneisyyden - kaventumista. Kenties juuri tästä probleemakentästä on kohonnut täydentävä ajatus, jonka mukaan autonomisuuteen on liitettävä kriittisyyden elementti. Näin ajateltuna kasvatus tähtää autonomian lisäämiseen, jos siinä edistetään kasvatin kykyä tehdä kriittisiä arviointeja. Kokonaan toinen asia on taas se, liittyykö näin ymmärretty autonomisuus elimellisesti nimenomaan sivistyksen tai sivistysprosessin käsitteeseen. Voidaan näet hyvin väittää, että kriittisyyteen ohjaaminen on arvo, ja arvojenhan katsotaan välittyvän juuri sosialisaation kautta. Kriittisyyttä ja siihen liittyvää

"Näin ajateltuna kasvatus täh-

tää autonomian lisäämiseen, jos

siinä edistetään kasvatin kykyä

tehdä kriittisiä arviointeja." autonomisuutta voitaisiin näin pitää sosialisaation tuloksena.[3]

$\mathrm{P}_{\mathrm{e}}$ dagogisen toiminnan ominaispiirteisiin luettu kulttuurin presentaatio - so. kulttuurin sisältöainekseen tutustuttaminen (ks. Kivelä 1997, 40-41) - ei liioin anna aihetta erottaa kasvatusta ja sosialisaatiota toisistaan. Näin siinäkin tapauksessa, että presentaatioon liitetään kulttuuritradition ylittämisen idea. Tähän perustuva erottelu rakentuu mielestäni kahden vähemmän onnistuneen perusoletuksen varaan. Ensinnäkin, sosialisaatioprosessilla ei tarvitse ymmärtää sitä, että varttuva ihminen omaksuu 'yksipuolisesti' tai 'täydellisesti' aikuissukupolven kulttuuritradition (ks. Kivelä 1997, 41-42). Sosialisaatio ei ole yksisuuntaista; tai kuten Giddens $(1989,60)$ asian ilmaisee, sosialisaatiota ei pidä ymmärtää 'kulttuurisena ohjelmointina'. Näin ollen vuorovaikutteisuutta ei tarvitse sulkea sosialisaatiokäsitteen ulkopuolelle. - Toiseksi, uuden luomiseen kannustaminen on - autonomisuuden tapaan arvoihin perustuva normatiivinen suositus, eikä se siten ole ristiriidassa sosialisaation idean kanssa.

$\mathrm{T}$ oisiko neljäs periaate eron esiin? - Kasvatustoiminnan tunnusmerkkinä pidetään sen suuntautumista kohden tulevaa, ja ei mitä tahansa tulevaa, vaan kohden parempaa tulevaa. Tästä Kivelä käyttää nimitystä kulttuurinen representaatio. Lisäksi hän väittää, ettei sosialisaatioon kuulu tällainen paremman tulevaisuuden tavoittelu. (Kivelä 1997, 42.) - Tähän on kuitenkin todettava, että miten niin ei kuulu. Mielekkäämpään tulevaisuuteen pyrkiminen edellyttää arvottamista (mielekkäämpi on kyettävä erottamaan vähemmän mielekkäästä), ja tämä taas edellyttää arvojen olemassaoloa. Ja juuri arvo- ja normitiedon omaksumisen on perinteisesti katsottu tapahtuvan sosialisaation kautta. Niinpä voidaankin väittää, että niin paremman tulevaisuuden tavoittelu kuin kulttuuritraditiossa pysyttäytyminenkin edellyttää tietynlaiseen arvomaailmaan mukautumista. Kulttuurinen representaatiokaan ei siis näyttäisi olevan vain kasvatukselle ominainen erityispiirre.

Sosialisaation ja kasvatuksen erottaminen toisistaan ei tahdo mitenkään soveltua suomalaiseen 
tapaan nähdä asiat. Termi 'Bildung' nostaa väistämättä esiin sivistyksellisyyden tai peri-ihmisyyden ideat, joiden kehkeytymiselle sosialisaatio voidaan nähdä enemmän uhkana kuin resurssina. Näin ei ole laita termin 'kasvatus' kanssa. Olisiko sitten niin, että sosialisaation ja kasvatuksen välistä suhdetta koskevat näkemyserot juontuvatkin ennen kaikkea kielellisistä eroavuuksista?

\section{Rakentuuko sosialisaatio/ kasvatus -erottelu kielieroille?}

Quomalaisittain ajateltuna tiedeyhteisön kantaa sosialisaation ja kasvatuksen välisen suhteen hahmottamista. Ratkaiseva virhe tehdään, jos termien sanakirjavastaavuus sekoitetaan merkityssisältöjen vastaavuuteen. Tähän liittyvää problematiikkaa on kuvattu 'sanan' ja 'käsitteen' termeillä. Tällöin sana on äänne- tai merkkijoukko, ja käsite on tuota äänne- tai merkkijoukkoa vastaava merkitys. Sanoilla on merkitys, ja tuo merkitys on käsitteeksi kutsuttu ajatuskonstruktio. (Rosing 1994, 39-45). Tähän liittyen on lisäksi väitetty, että käsitteen merkitys ei muutu, vaikka nimi vaihdettaisiin toisenkieliseksi. Näin ollen sanoja 'talo' ja 'das Haus' vastaisi sama talon käsite. (Teräväinen 1982, 14) [4]. Yksinkertaisten sanojen osalta tämä väite näyttäisi pitävän paikkansa, mutta päteekö sama periaate myös monimutkaisempiin termeihin? Ainakaan kasvatuksesta puhuttaessa tämä ei näyttäisi pitävän paikkaansa.

$\mathrm{K}$ uten jo edellä todettiin, termiin 'Bildung' iittyy merkitysvivahteita, joita suomen kieli ei tunne. Liioin englannin kielen termi 'education' ei ole merkitykseltään yhtenevä suomenkielisen vastineensa kanssa, sillä sana 'education' viittaa ensi sijassa kouluinstituutiossa annettuun kasvatukseen (E.B., 372 ; O.C. 1992, 338). Side on niin vahva, että kasvatuksen käsitettä kriittisestä näkökulmasta tarkastelevassa kirjoituksessa täytyy erikseen todeta, että kasvatusta voi tapahtua muuallakin kuin koulussa ja että kasvattajana ei aina tarvitse olla opettaja (Barrow ja
Milburn 1986, 84). Kyse ei ole kuitenkaan pelkästään koulutuksesta tai opin jakamisesta, sillä sanaan liittyy myös vahva arvottava latauksensa. 'Education' on "hyvää" kasvatusta, joka pitää sisällään tietojen ja taitojen opettamisen lisäksi myös luonteen kehittämisen (OEC 1989, 74; O.C. 1992, 338). Tässä mielessä 'education' on varsin lähellä saksan sanaa 'Bildung'. Näiden välillä vallitsee kuitenkin selvä ero. Sanan 'education' konnotaatio liittyy ei niinkään ideaaliseen ihmiseen kuin tuota ihanneihmistä tuottavaan instituutioon, siis kouluun. Saksassa tilanne on toinen. Termi 'Bildung' pitää sisällään paitsi yksilön henkisten kykyjen kehittämisen myös ajatuksen inhimillisyyden toteutumisesta ihmisessä. Siis siihen liittyy ajatus tavoittelun kohteena olevasta ihmisihanteesta. (Schwenk 1989, 208209; Meyer-Drawe 1999).

$\mathrm{O}$ tärkeää huomata, että termit 'Bildung' ja 'education' ovat teoriapitoisempia kuin suomenkielinen vastineensa. Näihin molempiin näyttäisi olevan jo valmiiksi sisäänrakentuneena käsitys siitä, mitä kasvatuksen pitäisi olla ja mihin kasvatuksella pitäisi pyrkiä. Britanniassa hyvä kasvatus näyttäisi tarkoittavan suurin piirtein samaa kuin "hyvän koulun käynyt" ja Saksassa taas "sivistynyt". Suomen kielessä tilanne on toisenlainen. Termiin 'kasvatus' ei suoranaisesti liity instituutioihin tai ihmisideaaliin viittaavia sivumerkityksiä. Itse asiassa, suomenkielinen termi voidaan ymmärtää varsin neutraalisti. Kasvatuksella pyritään hyvänä pidettyyn päämäärään ja kasvatus onnistuu, jos noihin päämääriin päästään.

$\mathrm{K}$ oska nykypäivänä englannista on tullut valitseva tieteen kieli, kannattaa tarkastella hieman tarkemmin termiin 'education' liittyviä erikoisuuksia. Ensikatsannolta näyttäisi siis siltä, että 'kasvatus' ja ‘education' ovat merkityssisällöltään kovin erilaisia. Kielihistoriallinen tarkastelu muuttaa hieman tätä vaikutelmaa, sillä englanninkielisen termin yhteys kouluinstituutioon ei ole aina ollut niin selvä kuin nykyisin. Termin käyttöala on ollut aiemmin huomattavasti laajempi. Niinpä 1600-luvun puolivälissä voitiin kirjoittaa, että ihmiset tekevät karkeita virheitä lastensa kasvatuksessa ("the education of 
children"), jolloin tarkoitettiin sitä, että lapsille tarjottiin toistuvasti vahvaa olutta ("I have seen some frequently give to their children strong Beere"). Tästä tekstikatkelmasta käy ilmi, että tuohon aikaan kasvatus piti sisällään myös ruokinnan. Tämän lisäksi termillä voitiin viitata yhtä hyvin lapsiin kuin eläimiinkin. (O.C. 1992, 338.) Tämä nykyenglannista lähes hävinnyt käyttötapa - esimerkiksi englanti-suomi suursanakirja (Hurme et al. 1990, 368) ei tätä merkitystä tunne - muistuttaa silmiin pistävästi termin 'kasvatus' käyttöä suomen kielessä. Aikaa myöten sanan 'education' merkityssisältö on siten huomattavasti kaventunut.

Viitteitä siihen, miten englannin kielessä on päädytty termin nykyiseen merkityssisältöön, antanee toinen, nyttemmin jo käytöstä poistunut merkitys. 1500-luvulla sanalla on tarkoitettu prosessia, jonka myötä nuori tulee tietoiseksi sosiaalisesta asemastaan, tavoista ja tottumuksista sekä ammattiurasta. Niinpä voitiin esitellä parhaita keinoja kasvattaa jalosukuisia lapsia ("the beste forme of education or bringing up of noble children"). (OEC 1989, 74; O.C. 1992, 338). Tästä on enää hyvin lyhyt siirtymä koulukeskeiseen kielenkäyttöön, sillä kuten tunnettua, Britanniassa yläluokkaisten lasten ideaalikasvatus kiteytyy Etonin tai Rugbyn tapaisiin hienostokouluihin. Nämä olivat antiikin ajoilta juontuvan reettorikoulun perinteenjatkajia, joten klassiset kielet ja ylipäätään kielenhuollolliset seikat olivat niissä keskeisen tärkeitä. Kun tähän liitetään 1800-luvun uudistustoimet, joilla aiemmin kurittomista laitoksista muokattiin herrasmiesten yhteisöjä (ks. Grue-Sörensen 1961, 210-219), on luotu vankka perusta koulukeskeiselle kasvatuskäsitykselle.

Hyvä kasvatus oli sitä, mitä hienostokouluissa annettiin. Se piti sisällään klassisten kulttuurien tuntemuksen, yläluokkaisen tapakoodeksin täydellisen hallinnan ja hienostuneen puheenparren. Tämä näkyy myös sellaisissa ilmauksissa kuin "educated accent", jolla tarkoitetaan vähintäänkin college-tason opinnot suorittaneen ihmisen ääntämistapaa, tai “educated English”, joka viittaa sisällöltään ja muodoltaan moitteettomaan kielenkäyttöön. Hyvän kasvatuksen saattoi näin
Niin pitkään kuin kasvatus koe-

tetaan kiinnittää ulkoisiin seik-

koihin - kuten erityiseen kasvatusinstituutioon (education) tai ideaali-ihmiseen (Bildung) - estytään näkemästä, että termit 'sosialisaatio' ja 'kasvatus' ovat erilaatuisia kielellisiä ilmauksia.

erottaa pelkän ääntämisen perusteella tai vaikkapa kaksoiskieltoa koskevan säännön rikkomisesta. (O.C. 1992, 338).

E liittikoulut ja niiden tuottama gentleman saatavat olla osasyy siihen, miksi englantilaisella kielialueella kasvatus on kiinnittynyt instituutioiden ominaispiirteeksi. Hyvä kasvatus on tällöin sitä, mitä hyvä koulutus voi tarjota. Nykyisin sanalla 'education' tarkoitetaankin tavallisesti formaalia kasvatusta, so. koulussa tai koulumaisissa laitoksissa tapahtuvaa kasvatustoimintaa. Tämä sitoutuneisuus instituutioihin saattaa myös osaltaan selittää, miksi termi 'education' jätetään usein tiedeteksteissä määrittelemättä. Näin voi käydä jopa teoksessa, jossa englanninkielisen otsikon mukaan pitäisi käsitellä kasvatuksen filosofiaa tai kasvatuksen teoriaa! Tällainen käytäntö on mahdollista vain silloin, jos termin 'education' merkityssisältö on huomattavasti yksiselitteisempi kuin kotoisen 'kasvatuksemme'. Näin todella näyttäisi asia olevan. Määrittely on tarpeetonta, jos termin katsotaan viittaavan vain tietynlaisten instituutioiden sisällä tapahtuvaan toimintaan. Eihän suomalaistenkaan tarvitse määritellä termiä 'kouluopetus'.

äyttää siis siltä, että 'education' ja 'kasva-
tus' eivät ole termeinä yhteismitallisia. Ne tarkoittavat erilaisia asioita. Mutta pelkkä erilaisuuden toteaminen ei vielä riitä. Jos on niin, että kahdessa kielessä "samaa asiaa" kuvataan sanoilla, jotka eivät ole keskenään vaihdettavissa so. niiden todellinen merkitysero on huomattava - on syytä kysyä, onko jompi kumpi merkityssisällöistä käyttökelpoisempi ajatellen ilmiö- 
kentän tieteellistä hahmottamista. Sosialisaation ja kasvatuksen väliseen suhteeseen liittyvä problematiikka on hyvä koetinkivi. Ainakin tältä osin näyttäisi siltä, että suomenkielinen termi tarjoaa hedelmällisemmän lähtökohdan kasvatuksen teoreettiselle haltuunotolle kuin englannin- tai saksankielinen vastineensa. Niin pitkään kuin kasvatus koetetaan kiinnittää ulkoisiin seikkoihin kuten erityiseen kasvatusinstituutioon (education) tai ideaali-ihmiseen (Bildung) - estytään näkemästä, että termit 'sosialisaatio' ja 'kasvatus' ovat erilaatuisia kielellisiä ilmauksia. Puhuttaessa sosialisaatiosta kieli toimii eri tavoin kuin puhuttaessa kasvatuksesta[5]. Edellisessä tapauksessa kieli toimii varsin neutraalina merkityksen siirtäjänä, jälkimmäisessä tapauksessa kieli arvottaa kohteensa. Sosialisaatiosta puhuttaessa tarkoitetaan yksilön mukautumista yhteisön elämismaailmaan, kasvatuksesta puhuttaessa tarkoitetaan yksilön hyvänä pidettyä mukauttamista.

\section{Kasvatus ja sosialisatio}

Kasvatuksen määritteleviä piirteitä ei pitäisi yrittää hahmotella jostain tietystä kasvatuskäsityksestä käsin. Nähdäkseni englannin kielen 'education' ja saksan 'Bildung' houkuttelevat tekemään juuri tällaisen määrittelyvirheen. Näissä nimenomaisissa kielissä, pitkästä kulttuurihistoriasta johtuen, on sisäänrakennettuna ajatus, että kasvatus on kuvattavissa joillakin yleispätevillä tunnusmerkeillä. Englannin tapauksessa nämä tunnusmerkit liittyvät tiettyyn instituutioon (koululaitos ja etenkin eliittikoulut), Saksassa taas kuvaan ihanneihmisestä, jonka realisoituminen kasvatissa oli kaiken kasvatustyön tavoitteena. Ei voi kieltää, etteivätkö nämä kasvatuksen ominaislaatua

\section{On vaikea kuvitella, miksi}

kasvatus ei olisi yksi sosialisaa-

tion muoto. Millä perustein

yhteisön toimintakykyiseksi

jäseneksi kehittymisen proses-sia

voitaisiin pitää kokonaan eri

asiana kuin kasvatusta? koskevat käsitykset olisi mielenkiintoisia ja ajatuksia herättäviä. Mutta se, että ajatukset ovat hyviä ja mielenkiintoisia, ei vielä merkitse sitä, että ne olisivat ilmiön teoreettisen haltuunoton kannalta hedelmällisiä. Niihin tukeutuen joudutaan näet väistämättä siihen, että joko samaistetaan kasvatus sosialisaatioon tai vaihtoehtoisesti erotetaan nämä selvästi toisistaan. Nämä eivät kuitenkaan ole ainoat vaihtoehdot. Sosialisaatio ja kasvatus voidaan nähdä toisiinsa liittyvinä ilmiöinä. Suomalaisittain ajatellen edelleen varsin käyttökelpoisena voidaan pitää Kivistön (Kivistö ja Vaherva 1981, 30) esittämää käsitekehikkoa, jossa sosialisaatio tarkoitti ympäristön sopeutumista, kasvatus tietoista sosialisaatiota ja koulutus institutionalisoitunutta kasvatusta. Näin ollen niin koulutus kuin kasvatuskin kuuluvat sosialisaation käsitteen alaan.

$\mathrm{N}$ äistä termeistä ongelmallisin on juuri kasvatus. Mistä tiedän, onko kyseessä kasvatus vai ei? Kivistön mukaan erottavana piirteenä on toiminnan tietoisuus. Kun ihminen A vaikuttaa tietoisesti ihmisen B toimintaan on kyseessä kasvatus. Tämä ei kuitenkaan vielä riitä. Näin hahmoteltuna kasvatuksen käsitteeseen olisi sisällytettävä väkivallalla uhkaamiseen perustuva pakottaminen ja ajatuksiin tiedostamatta vaikuttava manipulaatio. Mutta eiväthän nämä voi sisältyä kasvatuksen käsitteeseen! Määritelmää onkin sittemmin täydennetty siten, että kasvatuksella täytyy olla hyvänä pidetty päämäärä. Nähdäkseni tämäkään ei vielä riitä. On näet huomattava, että kasvatustoiminta erottuu pelkästä sosialisaatiosta nimeämisprosessin kautta. Kasvatus tunnistetaan kasvatukseksi. Nimettäessä jokin ilmiö kasvatukseksi siihen samalla liitetään tukuttain sellaisia merkityksiä, jotka kasvatuksen nimeen (sanaan, termiin) liittyy. Näistä tärkeimmät ovat juuri tarkoituksellisuus ja pyrkimys kohden hyvää päämäärää.

Nähdäkseni kasvatusilmiön teoreettisessa hahmottamisessa ei ole kyllin selvästi tuotu esiin tätä termin 'kasvatus' erityisominaisuutta. Puhuttaessa sosialisaatiosta viitataan vain tietynlaiseen prosessiin (yksilö mukautuu sosiaaliseen ympäristöönsä toimimalla interaktiivisesti sen kanssa). Parkkisakko, esitelmän pito, iltauutiset, opet- 
tajan puhuttelu, tohtoripromootio ja katurettelössä saatu nyrkinisku ovat kaikki osa sosialisaatioprosessia. Sen sijaan kasvatuksesta puhuttaessa välitetään ensi sijassa johonkin ilmiöön liittyviä asenteita. Kasvatus tähtää hyvään, se on oikeanlaista vaikuttamista. Käytettäessä sanaa 'kasvatus' samalla todetaan “tämä on oikein". Puhuttaessa sosialisaatiosta viitataan observoitavissa oleviin ilmiöihin, puhuttaessa kasvatuksesta viitataan tiettyihin kulttuurisiin merkityksiin (ks. myös Vogel 1996, 488-489). Jos tätä sanojen 'sosialisaatio' ja 'kasvatus' välistä eroa ei tunnisteta, ajaudutaan helposti käsitteellisiin umpikujiin. Niinpä esimerkiksi ulkoisten tunnusmerkkien etsiminen kasvatukselle on käytännössä mahdotonta. Viime kädessä nimeäminen ratkaisee, onko ilmiö kasvatusta vai ei.

$\mathrm{O}$ väitetty, että kasvatus on aina myös sosialisaatiota. Toisaalta on tähdennetty, että kaikki sosialisaatio ei ole kasvatusta, sillä jälkimmäiselle on ominaista toiminnan intentionaalisuus, tarkoituksellisuus. Näin ollen termit eivät ole ekvivalenttisia, kasvatusta ei voi redusoida sosialisaatioon. (ks. esim. Geulen 1989). Nimeämisprosessiin sidottu kasvatuskäsitys sopii yhteen tämän ajatuskulun kanssa. Korostettaessa sitä, että tietty ilmiö on tunnistettava kasvatukseksi, samalla kuitenkin laajennetaan intentionaalisuuden kriteeriä. Enää kasvatusta ei olisi vain se, jossa A tarkoituksellisesti vaikuttaa B:hen. Kasvatuksen tunnistamiseen riittää jo se, että B tai tilanteen ulkopuolinen tarkkailija $\mathrm{C}$ intentoi (havaitsee ja nimeää) kasvatusilmiön. Kasvatus on tunnistettava kasvatukseksi, ja juuri tämän tunnistamisen ja siihen liittyvän nimeämisprosessin kautta kasvatus erottautuu sosialisaatiosta. Ja tästäkään huolimatta nämä eivät ole erillisiä ilmiöitä.

$\mathrm{H}^{2}$ avainnollistan väitettäni analogialla. On olemassa toimintojen kenttä nimeltä pintakäsittely. Seinän maalaaminen on pintakäsittelyä. Seinä voidaan maalata monella tapaa. Niinpä Michelanglo maalasi Sikstuksen kappeliin freskoja. Yleisesti on hyväksytty ajatus, että nämä ovat osa taiteen maailmaa, ne ovat siis taidemaalauksia. Toisaalta on niin, että freskoihin voidaan soveltaa myös pintakäsittelyn termiä. Sosi- alisaation ja kasvatuksen erillisyyttä korostavaan ajatussuuntaan rinnastettuna pitäisi siis väittää, että pintakäsittely ja freskotaide eivät ole ekvivalentteja eivätkä edes hierarkkisia käsitteitä (ks. Peltonen 1997, 27-28). Näinköhän asia on? Michelangelon maalaukset ovat samanaikaisesti freskotaidetta ja pintakäsittelyä; ja pintakäsittely on kielen sisäisen logiikan kannalta yläkäsite verrattuna freskotaiteen (tai ylipäätään maalaustaiteen) käsitteeseen. Kaikki maalaustaide on pintakäsittelyä mutta kaikki pintakäsittely ei ole maalaustaidetta. - Tästä huolimatta ei tarvitse olettaa, että freskotaide ja pintakäsittely olisivat laadullisesti samankaltaisia. Ei. Maalaustaide eroaa laadullisesti pintakäsittelystä, mutta tuo laadullinen eroavuus ei liity siihen, miten pinta on käsitelty. Objektiivisia taiteellisuuden kriteereitä on yritetty turhaan muotoilla. Syy on yksinkertainen: taide tunnistetaan taiteeksi. Vastaavasti taiteen teoria tutkii sitä, mistä taiteen voi tunnistaa. Tällä tiedolla on ihmiselle erityistä arvoa. Jopa rahallista (taiteeksi tunnistettu romurauta on kalliimpaa kuin pelkkä romurauta).

Termikaksikko kasvatus ja sosialisaatio näyttäisi olevan analogisessa suhteessa sanapariin maalaustaide ja pintakäsittely. Sanaparien loppuosat (sosialisaatio, pintakäsittely) vain toteavat, että jotain on tapahtunut. Alkuosat (kasvatus, maalaustaide) sitä vastoin pitävät sisällään arvonäkökohdan. Kasvatus on aina jotain hyvää, samoin taide. Tämä on pidettävä tarkoin mielessä, sillä arvonäkökohtien tarkastelu ei tahdo oikein onnistua sosialisaation ja pintakäsittelyn näkökulmissa. Tässä mielessä kasvatus (maalaustaide) ja sosialisaatio (pintakäsittely) eivät ole ekvivalenttisia käsitteitä. Analogiaa jatkaen on kuitenkin tähdennettävä, kaikki kasvatus on aina myös sosialisaatiota. Vain silloin tämä periaate ei päde, kun puhumme toteutumattomasta, pelkäksi ajatuskuvajaiseksi jääneestä kasvatuksesta (tai: kontrafaktuaalisesta kasvatuksesta). Vain puhtaassa ideamuodossaan kasvatus voi jäädä sosialisaation käsitteen ulkopuolelle. Samalla tavoin mielessä kuviteltu mutta ainaisesti maalaamatta jäänyt mestariteos jää pintakäsittelyn käsitteen ulkopuolelle. Siitä taas voi hyvin keskustella, onko mielikuvamaalaus maalaustaidetta tai kuviteltu kasvatustoiminta kasvatusta. 
$\mathrm{M}$ utta tarjoaako lähestymistapa, jossa korostetaan sanojen 'sosialisaatio' ja 'kasvatus' käyttöön liittyvää laadullista eroa, jotain sellaista, mitä esimerkiksi sivistysperiaatteelle rakentuva teoria ei kykene antamaan? Mielestäni kyllä. Ensinnäkin ratkeaa kiusallinen pulma, millaista toimintaa voidaan pitää kasvatuksena ja millaista taas ei. Kasvatusta on se, jota kasvatukseksi kutsutaan. Voinko siis itse päättää, mitä ilmiöitä nimeän juuri 'kasvatukseksi'. Ei nyt sentään. Polkupyörän kutsuminen autoksi ei siitä vielä autoa tee, ja sama periaate pätee kasvatukseen. Jos joku väittää, että lapsen pahoinpitely on kasvatusta, silloin hän tosin saattaa käyttää kieltä oikein - eli puhuja itse katsoo päämääriensä olevan hyviä -, mutta intersubjektiivista hyväksyntää hän ei luultavasti tulisi käsityksilleen saamaan. Meidän mielestämme hän ei vain kasvata lastaan väärin vaan toimii kerrassaan rikollisesti. - Tällaisessa rajanvedossa ei tarvita absoluuttisia kriteerejä. 'Kasvatus' -sanan käyttöoikeus ratkaistaan paremman argumentin periaatteella, siis kriittisessä keskustelussa. Objektiivisten kriteereiden esittäminen ei tällaista keskustelutilannetta suosi. Absoluuttiset kriteerit johtavat helposti absoluuttiseen hiljaisuuteen.

$\mathrm{T}$ oiseksi, kuvattu lähestymistapa ratkaisee mm. piilo-opetussuunnitelmaan liittyvän problematiikan. Periaatteessahan tätä asiakokonaisuutta ei voisi lainkaan tarkastella kasvatuksen näkökulmasta, koskapa siinä ei ole kysymys tietoisesta vaikuttamispyrkimyksestä. Mutta lähdettäessä liikkeelle siitä, että kasvatusilmiön tunnistamisessa keskeisen tärkeässä asemassa on ilmiön nimeäminen, silloin tilanne muuttuu ratkaisevasti. Jos nyt otan esille koulutuskäytännöstä jonkin seikan - vaikkapa pätemättömyyden tuottamisen - ja totean, että elinikäisen oppimisen ideologia iskostaa osaan ihmisistä sellaisen käsityksen, että heidän pärjäämättömyytensä elämässä on yksilöllis-kognitiivinen eikä yhteiskunnallissosiaalinen ongelma, silloin tuosta seikasta konstituoituukin kasvatuksen kenttään kuuluva ilmiö, jota voidaan tarkastella kuin kasvatusta ikään. Tällainen lähestymistapa tarjoaa siten uusia näkökulmia sellaiselle tutkimukselle, jossa kasvatusta tarkastellaan yhteiskunnallisten rakenteiden näkökulmasta. Tutkija voisi tunnistaa esimerkiksi verotuksesta piirteitä, jotka ovat kasvatukselle ominaisia. Tästä avautuisikin mielenkiintoinen tutkimussarka, sillä demokraattisessa yhteiskunnassa verotus on kiistatta merkittävin aikuiskasvatuksen työkalu.

$\mathrm{K}^{\mathrm{s}}$ olmanneksi, edellä esitelty tapa suhteuttaa oisiinsa sosialisaatio ja kasvatus luo tarvittavaa yhtenäisyyttä ihmistutkimuksen kenttään. Sosialisaatiossa ihminen on interaktiossa sosiaalisen ympäristönsä kanssa. Kasvatuksessa pyritään tietoisesti vaikuttamaan yksilöön, sosiaalistamaan häntä hyvänä pidettyyn suuntaan. Se, mitä pidetään hyvänä, riippuu taas kulloisestakin kasvatuskäsityksestä. Kasvatuskäsitykset taas ovat muotoutuneet - ainakin osittain! - sosialisaatioprosessissa. Näin niitä ei mitenkään voisi pitää erillisinä eikä varsinkaan toisensa poissulkevina ilmiöinä.

Sosialisaation kammo saattaa osin juontua determinismin pelosta. Ihmisen pelätään kutistuvan passiiviseksi olioksi, joka sosialisaatioprosessissa tungetaan tietynlaiseen muottiin. Tästä ei toki ole kysymys. Yksilö ja ympäristö ovat keskenään vuorovaikutuksellisessa suhteessa. Lisäksi ei pidä vähätellä sitä tosiasiaa, että ihminen tulee ihmiseksi ensi sijassa kielensä kautta. Inhimillinen todellisuus - myös 'sivistys' - välittyy, todentuu ja uusintuu kielessä. On tosin tähdennettävä, että tältä osin sosialisaatioprosessi on melkoisen yksisuuntainen: kieltä omaksuessaan yksilö on pääasiassa vastaanottava osapuoli, ja tämä pätee myös vieraan kielen opiskeluun. Kielen näennäinen yksiselitteisyys saattaa estää havaitsemasta ilmaisuihin sisältyviä esiteoreettisia merkityssisältöjä. Näin arkipuheen sisältämä teoreettinen aines voi siirtyä lähes sellaisenaan osaksi tiedepuhetta. Tästä syystä voisi hyvin väittää, että autonomiaan, kriittisyyteen, itseohjautuvuuteen tai muuhun vastaavaan tähtäävän kasvatuksen olisi pyrittävä luomaan yksilölle valmiuksia arvioida uudelleen omaa kieliperintöään - ja ehkäpä myös oman tieteenalansa kielellisiä käytäntöjä.

\section{Huomautuksia}

Puhe sosialisaatiosta inhimilliseen elinympäristöön sopeutumisena edustaa tietenkin vain eri- 


\section{I $k$ o $n$ e $n$}

tyistä tapaa ymmärtää sosialisaation perusluonne. Termillä 'sosialisaatio' on useita merkityksiä riippuen siitä, mistä näkökulmasta ilmiötä lähestytään (ks. Gecas 1992). Olen tiivistänyt eri lähestymistavat seuraavasti: sosialisaatioprosessissa yksilö tunnistaa ja omaksuu arvoja, tietoja ja taitoja. Tarkennukset yhteiskunnan jatkuvuuden, identiteetin muodostuksen tai kulttuuriaineksen siirron osalta eivät tätä perusideaa kumoa.

2 Tätä aihepiiriä valottaa mainiosti Siljanderin toi2 mittama teos Kasvatus ja sosialisaatio (1997) ja erittäinkin kyseiseen teokseen sisältyvä Ari Kivelän artikkeli (Kivelä 1997).

2 Näin vuonna 1970 julkaistu Pädagogisches Lexi3 kon asian näkeekin. Sen mukaan sosialisaation tuloksena voi olla yhtä hyvin yksilön autonomisuus kuin riippuvuuskin.

4 Termin käsite käyttöä voi tässä yhteydessä kritisoida. Nähdäkseni on perustellumpaa todeta, että sanojen 'talo' ja 'das Haus' merkityssisältö on likimain sama.

5 Korostettakoon sitä, että kyse on erilaisista ta$\mathcal{O}$ voista käyttää kielen sanoja. Jos kasvatus yritetään nivoa joihinkin objektiivisiin/absoluuttisiin lainalaisuuksiin - kuten aikuisten pyrkimyksiin kehittää varttuvassa sukupolvessa elämässä tarvittavia taitoja ja tietoja (ks. Tornberg 1998) - ajaudutaan väistämättä umpikujaan. Yritys on yhtä toivoton, kuin koettaa luoda universaaliestetiikkaa.

\section{Kirjallisuus}

ANTIKAINEN, A. (1993). Kasvatus, koulutus ja yhteiskunta. Porvoo: Wsoy.

ANTIKAINEN, A. (1998). Kasvatus, elämänkulku ja yhteiskunta. Porvoo: Wsoy.

BARROW. R. JA MILBURN, G. (1986). A critical dictionary of educational concepts. Brighton: Wheatsheaf Books.

BERTRAM, H. (1989). Sozialisation. Teoksessa: Staats Lexikon, fünfter Band, 4-6. Freiburg: Verlag Herder.

E.B. = The New Encyclopaedia Britannica. Vol. 4, 15th edition

GECAS, V. (1992). Socialization. Teoksessa: E.F. Borgatta (toim.) Encyclopedia of Sociology, Volume 4, 1863-1872. New York: MacMillan Publishing Company.

GEULEN, D. (1989). Sozialisation. Teoksessa: Dieter Lenzen (toim.) Pädagogische Grundbegriffe 2, 1409-1416. Hamburg: Rowohlts Enzyklopädie.

GIDDENS, A. (1989). Sociology. Oxford: Polity Press.

GRUE-SÖRENSEN, K. (1961). Kasvatuksen historia. Toinen osa, Pestalozzista nykyaikaan. Helsinki WSOY.

HURME R., Pesonen, M \& Syväoja O. (1990). Englantisuomi suursanakirja. Porvoo: Wsoy.

KARJALAINEN, A. ja Siljander, P. (1997). Pedagogisen tietoisuuden paradoksi. Teoksessa: P. Siljander (toim.) Kasvatus ja sosialisaatio, 66-76. Tampere Gaudeamus
KIVELÄ, A. (1997). Pedagoginen toiminnanteoria ja sosialisaatioteoria. Teoksessa: P.Siljander (toim.) Kasvatus ja sosialisaatio, 32-65. Tampere: Gaudeamus.

KIVISTÖ, K. \& Vaherva T. 1981. Kasvatussosiologia 5. uudistettu painos. Jyväskylä: Gummerus.

MEYER-DRAWE, K. (1999). Zum metaphorischen Gehalt von 'Bildung' und 'Erziehung'. Zeitschrift für Pädagogik 45, 2, 161-175.

NEIHARDT, F. (1970). Sozialisation. Teoksessa: Pädagogische Lexikon in zwei Bänden, Zweiter Band K-Z, 1053-1055. Güterslohe: Bertelsmann Fachverlag.

O.C. $1992=$ The Oxford Companion to the English Language. Edited by Tom McArthur.

Oxford: University Press.

OEC 1989 = The Oxford English Dictionary, Volume V. Second edition. Oxford: Clarendon Press.

PELTONEN, J. (1997). Sosialisaatio ja kasvatus empiirisen tutkimuksen näkökulmasta. Teoksessa: P.Siljander (toim.) Kasvatus ja sosialisaatio, 1431. Tampere: Gaudeamus.

ROSING, H. (1994). Vetenskapens logiska grunder. Hangö: Schildts.

SCHWENK, B. (1989). Bildung. Teoksessa: Dieter Lenzen (Toim.) Pädagogische Grundbegriffe 1, 208221. Hamburg: Rowohlts Enzyklopädie.

SILJANDER, P. (1997). Kasvatus ja sosialisaatio - johdatus aiheeseen. Teoksessa: P.Siljander (toim.) Kasvatus ja sosialisaatio, 7-13. Tampere: Gaudeamus

SILJANDER, P. (toim.) (1997). Kasvatus ja sosialisaatio. Tampere: Gaudeamus

STURMAN, A. (1997). Socialization. Teoksessa: Lawrence J.Saha (toim.) International Encyclopedia of the Sociology of Education, 528-533. Oxford: Pergamon

TERÄVÄINEN, J. (1982). Johdatus filosofiaan. Saarijärvi: Kirjapaja.

TORNBERG, A. (1998). Ovatko sosialisaatio ja kasvatus samoja käsitteitä? Aikuiskasvatus 18, 3, 248250 .

VOGEL, P. (1996). Scheinprobleme in der Erziehungswissenschaft: Das Verhältnis von 'Erziehung' und 'Sozialisation'. Zeitschrift für Pädagogik 42, 4, 481-490

\section{Taustaksi}

$\mathrm{R}$ isto Ikonen väitteli 1997 kasvatushistorian alaan kuuluvalla tutkielmallaan Ábo Tidningar 17711808 ja kasvatusyhteiskunnan idea. Hänen työhönsä Joensuun yliopiston kasvatustieteen laitoksen yliassistenttina kuuluu $\mathrm{mm}$. tieteenteoriaan liittyvä opetus. Kasvatusfilosofisia aiheita hän on käsitellyt erilaisissa tiedetapaamisissa. Ennen yliopistouraa Ikonen toimi kahdeksan vuotta luokanopettajana.

A ikuiskasvatuksen toimituskunta päätti pyytää $\mathrm{Ou}$ Alun yliopistosta kommenttipuheenvuoron Risto Ikosen artikkeliin. Julkaisemme ARI KIVELÄLTÄ saamamme kommenttipuheenvuoron edellä julkaistun artikkelin jatkoksi.

Artikkeli saapui toimitukseen 22.10.1999. Se hyväksyttiin julkaistavaksi 13.12. 